\title{
酒造の省力化に関する 2 3 の研究
}

$\begin{array}{llll}\text { 河 } & \text { 村 } & \text { 稔/愛知県食品工業試験所 } \\ \text { 山 } & \text { 下 } & \text { 勝 } \\ \text { 柴 } & \text { 田 } & \text { 正 } & \text { 人 }\end{array}$

今回の清酒製造業近代化実施計画は技術および技能の 向上に関する事項で，製造工程に挌ける労働力の節减ま たは省力化の実施を強くとりあげている。私達も酒造の 省力化に関して機械製檄をはじめ諸研究を行なってきた が，ここでは最近試験した $2 \sim 3$ のものについて簡単に 解説して見たい。

\section{I 酒會内における原料米等の輸送}

精米した白米を洗滌しつつ浸漬桶に輸送するには既に ソリッドポンプ, サンドポンプ等を利用し, 労働力の節 减に大いに役立っているが1)，これらのポンプを使用す る場合途中でホースに米がつまって輸送が困難になった り，用水が非常に大量に必要であったり，砕米ができた りして思わ奴失敗がないでもない。このような失敗はポ ンプの能力, ホースの抵抗，水と米との混合量比等の関 係について正確な知識を欠いているためではないかと思 ら。蒸米の空気輸送についても同様なことがい光る。 まずポンプの能力は馬力数に比例するのであるから， 一度に大量のるのを送ったり，あるいは遠距離や高所に 輸送するにはとれ相応の馬力のものを用いねばならな い。案外小さな馬力のものを使って送れないと不平をい ったり，大き過ぎるものを備えて無䭾をする場合が多 い。事前によく調查して適当なものを使用すべきであ る。

次は輸送管の抵抗が意外に大きいことを計算に入れる 必要がある。距離の長いほど, 揚程の高いほど, ホース の曲りが激しい棌ど抵抗は強くなる。したがって同じ位 置まで送るにもなるべくホースの抵抗の少ないように配 管せねばエネルギーの損失が大となる。

さらに米と水（または空気）との混合量比が非常に問 題で，一般的には短距離で水平直線の場合は水の量比は 少なくてもよいが，長距離に送ったり高所で垂直上昇部 の多いときには水の量を多くして米量の $3 \sim 5$ 倍にせ敉 ば輸送できない場合が多い。即ち米の量比が大になるほ
ど加重と抵抗が增し流速が落ちるため米の輸送が困難に なる。また我を極端に少なくしたり, 輸送の中断をした りすると米が水を吸収して膨脹しホースにつまることも。 あり洗米が不充分になったり碎米ができることる考学ね ばならない。蒸米の空気輸送ではこのほかに固り(団子) の大きさが非常に影響するようである。

次に当所に批ける洗米搬送ポンプ（サンドポンプ）の 性能試験の結果について報告する。

使用ポンプ 岩瀬式洗米搬送ポンプ 価格 8 万円

性 能 口径 2 时, 電力三相 $200 \mathrm{~V} 1.5 \mathrm{~kW}$

( $2 \mathrm{PP})$, ポンプ回転数 1750 R.P.M.

\section{1. 輸送能力について}

（a）送水能力 $720 \mathrm{l} / \mathrm{min}=42,000 \mathrm{l} / \mathrm{hr}$ 最高揚程 $11.62 \mathrm{~m}$ 約 $1.2 \mathrm{~kg} / \mathrm{cm}^{2}$

軟質塩ビホース（2 时） $20 \mathrm{~m}$ をポンプにとりつけ各 高さの位置までの送水量を調査した結果は次のようであ る。

$\begin{array}{ccc}\text { 高さ } & 1 \text { 時間の送水量 } & 1 \text { 時間の洗米輸送量 } \\ 11 \mathrm{~m} & 3530 l & - \\ 10 \mathrm{~m} & 7380 \mathrm{l} & - \\ 8 \mathrm{~m} & 13970 \mathrm{l} & 2100 \mathrm{~kg} \\ 6 \mathrm{~m} & 19000 \mathrm{l} & 3500 \mathrm{~kg} \\ 4 \mathrm{~m} & 23420 l & 4700 \mathrm{~kg} \\ 0 \mathrm{~m} & 42700 l & 6500 \mathrm{~kg} \text { (ホースのないとき) }\end{array}$

洗米輸送量は水：米の比を $3: 1$ とした場合の計算式 から推定したものである。いずれも高い所ほど輸送量は 減少する。

（b）使用不能帯および不安定带

米粒の水中に㨟ける自然沈降速度は約 $18 \mathrm{~cm} / \mathrm{Sec}$ であ. るから, 輸送速度がこれ以下では米の輸送は不能であ り, この 3 4 倍の流速（約 $65 \mathrm{~cm} / \mathrm{Sec}$ ) 以下は不安定 帯である。このポンプでは揚程 $10 \mathrm{~m}$ 附近がその点にあ. たり, 水と米の量比が $3: 1$ の場合は高さなら $10 \mathrm{~m}$, 水平距離ならば70〜100 $\mathrm{m}$ が米を送り得る限度となる。

(c) 輸送可能濃度

2 时の軟質塩ビホース $20 \mathrm{~m}$ を使用してほとんど水平 
で実際に白米を輸送したときの結果は, 水と米の比が ○.7:1 まで輸送可能であったが,一般には $3: 1$ 位の使 用が望ましい。またそのときの輸送量を調査した結果は 次のようであった。

$\begin{array}{lcr}\text { 水対米の比 } & 1.5: 1 & 3: 1 \\ \text { 全輸送量 } l / \mathrm{hr} & 10000 & 21000 \\ \text { 白米愉送量 } \mathrm{kg} / \mathrm{hr} & 4500 & 5600\end{array}$

即ち水を少なくすると輸送力が减少する。従って遠距 離や高所の場合は特に水を多くすることが必要で白米輸 送量る增加する。 $3: 1$ の場合は 1 時間に約 37 石を洗 米することができた。

\section{(d) 輸送管の抵抗}

ホースの長さと高さの抵抗関係は次式で現わされる。

全揚程 $\mathrm{m}=$ 高さ $\mathrm{m}$ 十長さ $\mathrm{m} \times 0.15 \sim 0.23$

水: 米の比を $3: 1$ とするとこのポンプの場合は前述 のように全揚程が $10.5 \mathrm{~m}$ であるから, 高さ $6 \mathrm{~m}$ とすれ ば長さ $30 \mathrm{~m}$ まで, 高さ $4 \mathrm{~m}$ とすれば長さ $45 \mathrm{~m}$ 附近ま では充分輸送可能であるが，それ以上のときには濃度を 下げるか馬力の大きなるのを使用せねばならない。また 2 时ホースの場合曲りの抵抗は直径の 20 倍位の直線距 離に相当するからなるべく曲りの少ない方がよい。特に 垂直に上昇する曲りの個所には米がつまり易いから注意 し，つまった米は速かに排出し得るような装置を施して 扣くのが無難である。ホースは円型のものがよく，ヒズ ミができると抵抗が大になることは当然である。

\section{2. 洗條能力について}

水: 米の比が $3: 1$ のとき $20 \mathrm{~m}$ のホースで試験した 結果は約 $4 \%$ の棣分が残ったのみで普通洗米機の能力と 差はなかった。この場合も水の量が多くホースの長いほ ぞ洗米性が向上することは当然である。

洗米のとき輸送管の出口で水切りを行ない, 水を張っ た浸漬桶の中へ少量の水をオーバーフローさせながら米 を送入するようにすればワラクズ等の爽雑物は水面に浮 いてらまく取り除くことができた。また一度水を切って 上部から清水をかければ一層洗滌効果が上る。碎米の程 度は普通洗米機と大差なかった。

以上が試験結果の概要であるが, ソリッドポンプやこ の種のサンドポンプを上手に利用すれば白米を精米所か ら釜場まで人手を要せず楽に洗米しつつ輸送することが できてまことに便利であるから大いに活用すべきだと思 3。

な特この種のポンプを用いて仕込時の蒸米を汲水と共 水送って仕込む方法や醪の輸送も当然可能と考兄られる が, これらの点については現在試験中である。上記の結 果は当所で行なった 1 機種についての結果であるが, 他 機種についての報告を期待している。

\section{II 醪の製造法について}

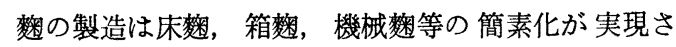
れ, 酒母製造に扔いて子高温糖化, 高温速醸, 快速山廃 等の研究が行なわれ, 暖気廃止や暖気操作の簡略化が実 施されて省力化に役立っているが，醪の製造方法につい てはアルコール添加と増醸法による增量が行なわれてい るだけで原醪は昔の型そのままであってスッポン仕込と か汲水歩合の増加が行なわれているに過ぎない。裂の 性状は直接清酒の香味につながるものであるから，製造 方法を根本的に変更し画期的な新しい方法を実施するに は相当な困難がともならので慎重にせねばならないのが 大きな原因となっているようである。しかし醪製造の簡 素化について全然研究がないのではなく添整仕込 ${ }^{2)}$, 酒 母省略仕込 ${ }^{3) 4}$, 酵素剂仕込 ${ }^{5)}$, 連続発酵(6)11) 等の研究が ある。それらについて当所で試験した結果について述べ る。

\section{（a）添仕込と酒母廃止酸}

添䊝仕込というのは掛整の全部を初添仕込み飞使用 し，仲留は蒸米のみで仕込む方法であって当所に扣いて は昭和 36 年度》から全部の醪をこの方法で製造してい る。製整のとき添, 仲, 留の区分をする必要がないので 床䊝や機械楼には便利であり, また仕込操作も都合のよ い時刻にやれる自由さがある。釈の力が酒母の酸で弱ま るのではないかと心配する人もあるが，その繋念はな く，むしろ初添で敉からの栄養分が多くなるために酵母 の発育が旺盛となり，醪経過が前急型になる場合が多 い。従って酒質は酸の少な目の温雅なるのになる傾向で 粕歩合その他の歩合は普通仕込々何等差異はないようで あるから，この方法を実際活用するのる面白いのではな いかと思う。当所ではこの方法で酒母廃止を行なったが まことに簡単な仕込みで効果をあげることができた。

次に酒母廃止醪については既に発表8)したように昭和 31 年度から毎年 $2 \sim 3$ 本の醪をこの方法で仕込んでいる が成績は極めて良好である。最近業界でも糖蜜や圧摍酵 母を用いて実施しているょうに報ぜられているがまこと に結構なことで大きな進歩ではないかと考劣る。

この方法は酒母の代りに純粋酵母のみで仕込むのであ るから, 初添時の酸の添加量, 酵母の活性度と添加量, オドリの温度と期間さえあやまらねば少しも不安はなく 安全であって, 酒母製造の手間が省けるのであるから省 力化には大いに役立つものである。

しかし製成酒の酒質は山廃使用のものに比べればやや 淡麗に過ぎるきらいがあるから，椈や醪の経過中にその 欠点を補 $っ 5$ 心掛ける必要がある。これらの点に注意 して純粋醭母大量生産と運搬が簡便にできるようにな 
れば清酒製造の工業化に大きな役割を果たす可能性があ るものと思う。

\section{(b) 䣼素剈添加仕込亡多段仕込}

酵素剤添加仕込は昭和 $31,37,38$ 年度の 3 回にわた って行なった。昨年度 ${ }^{9}$ は畨歩合を $13 \%$ に減少し, 本 年度 ${ }^{10}$ は更に $10 \%$ に減少してその不足分を市販アミラ 一ゼ（天野製薬K Kのビオジっス A とグルクザイムの併 用）の添加で補力する方法をとった。

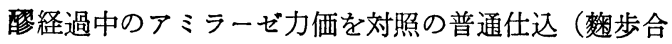
20〜23\%のもの）と比較したがやや低い値を示す程度 で剹の末期まで大差はなかった。品温経過は順調で成分 変化もかわりないが状貌は少し泡が高くチミッであった。 オリ量が少し多かったが粕歩合・酒化率は次のように普 通であった。

\begin{tabular}{|c|c|c|c|c|}
\hline \multirow[b]{3}{*}{ 齿 会 } & \multicolumn{2}{|c|}{37 年度 } & \multicolumn{2}{|c|}{38 年度 } \\
\hline & 1 & 2 & 1 & 2 \\
\hline & $13 \%$ & $13 \%$ & $10 \%$ & $10 \%$ \\
\hline 最高温度 & $16^{\circ} \mathrm{C}$ & $16^{\circ} \mathrm{C}$ & $16^{\circ} \mathrm{C}$ & $15^{\circ} \mathrm{C}$ \\
\hline 酸 日 数 & 25日 & 22日 & 21日 & 22 日 \\
\hline 粕 步 合 & $19.7 \%$ & $21.0 \%$ & $24.5 \%$ & $22.5 \%$ \\
\hline 酒 化 率 & 35.3 & 32.0 & 34.2 & 35.1 \\
\hline
\end{tabular}

37 年度は甘口傾向に導き, 38 年度は辛口酒にしたが 製成酒の香味は対照の普通仕込のものとほとんど区別す ることができなかった。

これらの経験から䴹歩合を半量程度をで減少しても， 䤃素剤を添加して補力すれば順調な醪を製造し得ること がわかったのであるが，今後は添加する酵素剤の組成と 量(現在は酒税法で原料米の $1 / 2,000$ 以下となっている) 添加時期等をさらに検討して完全なものにして清酒製造 の簡素化に役立てたい。現在でも数室が小さくて止むな

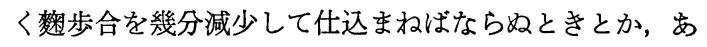
やまって力の弱い敕しかでき得なかったとき，または酸 の溶けが悪くてイラ湧き傾向になり易いとき等には酵素 剤を利用して殄を順調に導き安全を期するのがよい。 た醪中の酵素量を人為的に加減することによって清酒の 蛋白混濁予防の道が開らかれれば誠に結構なことである。 多段仕込とは本年度 ${ }^{10)}$ 醪の仕込配合を簡素化するため に添·仲・留の 3 段の区別を廃し，5段仕込として各段と も同一量の蒸米・船・汲水量として仕込んだものである が，その成績は普通仕込のものと全然かわりはなかった。 このことから推察すると現在の難かしい仕込配合はもっ と簡単にすることができ，段数の增減も可能で工業的な 画一の仕込配合にすることがでさよう。そうすれば毎日 の原料米の払い出し量も一定になり神経を使わないでも よくなり省力化にも役立つことになるのではないかと思 5。

（c）連続発酵予備試験

清酒が外国のビールのように連続発酵でオートメイシ
ョン式に製造できるようになれば面白いことになりそう であるが，規在のよらな平行複発䣼で半固体の清酒裂で はその可能性はほとんどない。だからといって清酒の連 続発酵は不可能だとあきらめてしまうのも早計で, 研究 して見なければ成否はわからない。また研究しているう ちに新しい醪の管理方法とか, 現在の清酒の長所を活か し短所を補うような製造方法が見つからないとは限らな い。そんな意味で 38 年度からこの研究に手をかけ始め たのである。

発酵を連続化するためには単式発酵即ち糖化と発酵を 別々にせねば難かしい上らであるが, 富金原氏 ${ }^{11)}$ もい ているように単式発酵でつくった清酒の酒質が果して従 来の清酒の酒質にまさるとも劣らないようなものになし 得るかどうかがまず第一に問題となる。そこで本年度は 手初めとして糖化と発醅を別々にして清酒を仕込んで見

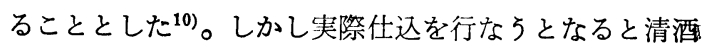
醪のような濃度の高いものを果してらまく糖化し得るだ ろらか，また桾化したとしてもうまく仕込温度索で朎却 できるだろらか，その間にバクテリアがきて酸敗するこ とはないだろらか, また糖化後はどのように添加して行 けばよいだろらかいろいろな心配がでてきたので，まず フラスコで予備試験を行なってから実際の仕込にとりか かった。

その結果仕込配合は次表のように 7 段としたが，これ は予備試験で各段の仕込量が前段合計の 5 割ではやや湧 き扣さ光気味であったので 4 割にしたことと，第 1 段 （酒母に相当するもの）を少量にして湧きを強くし全体 の裂の酸量を少なくしょうとしたためである。また糖化 とその後の冷却を容易にするために汲水歩合は $180 \%$ にのばし麴歩合は $27 \%$ に增加して行なって見た。

\begin{tabular}{|c|c|c|c|c|c|c|c|c|c|}
\hline \multicolumn{2}{|c|}{ 仕込配合 } & 1 段 & 2 段 & 3 段 & 4 段 & 5 段 & 6 段 & 7 段 & \multirow{2}{*}{$\begin{array}{c}\text { 計 } \\
100 \mathrm{~kg}\end{array}$} \\
\hline 棇 & * & $10 \mathrm{~kg}$ & 6 & 9 & 12 & 15 & 20 & 28 & \\
\hline 蒸 & 米 & $7 /$ & 4 & 6 & 9 & 11 & 15 & 21 & $73 /$ \\
\hline$こ 5$ & “米 & 31 & 2 & 3 & 3 & 4 & 5 & 7 & $27 "$ \\
\hline 汲 & 水 & $25 l$ & 10 & 15 & 20 & 25 & 35 & 50 & $180 l$ \\
\hline & $-x$ & $36 \%)$ & & & & & & 15 & $15 l$ \\
\hline
\end{tabular}

各段とも仕込 1 日前に糖化を行ならのであるが，その 方法は蒸米と猌を汲水 $150 \%$ で $55^{\circ} \mathrm{C}$ 亿加温し一晚（約 17 時間）保温し, 次いで糖化タンクを半切の中に入れ て井水で外側から冷却し,さらに冷却した残水を加えて 予定温度まで下げて仕込んだ。冷却時間は約 30 分間で あって糖化も冷却も案じるよりも容易に行ならことがで きた。こうしてできた各段の糖化液のボーメ拉よび直糖 は次のようであった。

$\begin{array}{lccccccc} & 1 \text { 段 } & 2 \text { 段 } & 3 \text { 段 } & 4 \text { 段 } & 5 \text { 段 } & 6 \text { 段 } & 7 \text { 段 } \\ \text { ボーメ } & 16.2 & 16.2 & 17.0 & 16.4 & 17.3 & 16.5 & 16.0 \\ \text { 直 楛 } & 27.68 \% & 25.80 & 26.36 & \text { - } & \text { - } & 25.60 & \text { - }\end{array}$

第 1 段では高温糖化酒母るつる要領で糖化したもの に乳酸を添加し $16^{\circ} \mathrm{C}$ に冷兄た所で醅母を添加した。翌 


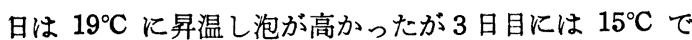
ボーメ 3 となったので第 2 段の糖化液を $16^{\circ} \mathrm{C}$ で添加し た。かくして1日扣きて7段まで仕込を行なったが，型 の温度は大体 $16^{\circ} \mathrm{C}$ を常に保っていた。各段の仕込前の ボーメは次表のよ5に大体 2.5 附近で仕込終了直後は 7 附近であった。

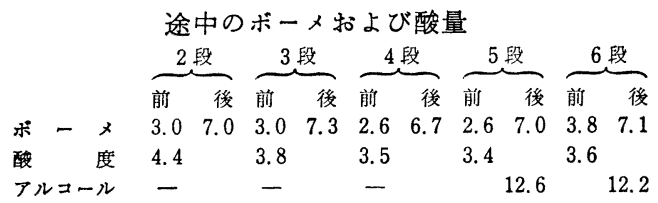

酸度は 1 段での添加量が多過ざたため後半までやや多 くなったが，途中の増加がないので初めの添加量を減少 すればもっと少量にすることが可能であることを知っ た。ボーメは 2 日で 4 位切っている。従って 7 段目の仕 込が終ると 2 日間でボーメ 2 となったので $10^{\circ} \mathrm{C}$ 以下に 温度を下げアルコール添加を 7 段仕込後 5 日目（1 段仕 込後 18 日目) に行なった。その時の成分はアルコール $14.1 \%$ 酸度 3.6 日本酒度一7 であった。

糖化後の冷却を開放で行なったのでバクテリアの增殖 を心配したが経過中の細菌数掞よび酵母数は次の通りで 異状は認められなかった。

\begin{tabular}{cccccc}
\multicolumn{7}{c}{ 細菌および酵母数 } \\
& 3 日目 & 5 日目 & 8 日目 & 11 日目 & 14 日目 \\
細菌数 $\times 10^{2}$ & 78 & 48 & 43 & 120 & 15 \\
醉母数 $\times 10^{7}$ & 18 & 15 & 8 & 9 & 14
\end{tabular}

8 日目に生酸菌がみられたが 11 日目には認められな かった。細菌数は全体を通じてほとんど $10^{3}$ であり通常 の醪と差はなかった。また䤃母数は普通裂よりやや少な い数を示した。顕徽鏡で見ると非常に多くの酵母が常に 出芽状態にあったが，これはた觉ず糖化液を添加するた めと添加によるアルコール等の稀釈が原因ではないかと 考觉られ。

このよ5に糖化液を 7 段に仕込んで連続発酵に近い状 態を造って見たのであるが，酵母は常にアルコール 12 $\sim 14 \%$, 酸度 $4 \sim 3.5$, ボーメ 7 2 の成分の醪中で 1 日 にボーメ 2 切る程度の発酵を 15 日間持続した。

製成酒の香味は普通酒に比してやや色が濃く，味がき たなく酸の多いものとなったが，これらの欠点は今後あ る程度改良できるもののようである。即ち色と味をきれ いにするためには数歩合・糖化条件・醪温度の検討が必 要であり, 酸については琴のボーメ特に第 1 段のボーメ を変えることによって酸の添加量を減少することができ る。また汲水歩合も $150 \%$ 位にすることが可能であるか らアルコール濃度も上昇し得るであろうし,さらに增䁔 酒にすれば成分のバランスを容易に加減することも考兄 られる。製成酒の成分拉よび粕歩合等は次のようであっ
た。

$$
\begin{array}{lrll}
\text { アルニール } & 16.4 \% & \text { 日本酒度 }+5 . & \text { 酸度 } 3.0 \\
\text { 粕 步 } & 22 \% & \text { 酒化率 } 38.7 &
\end{array}
$$

以上の上5に連続発酵の予備試験として糖化と発酵を 別々にして仕込を行なったが，その結果は初め心配した ような失敗もなく健全な醪をつくることができた。製成 酒の香味はけっして満足すべきものではなかったが，今 後さらに諸条件を検討することによって向上し得る自信 をもつことができた。

\section{III 上槽についての検討}

現在清酒の製造工程中で最も機械化省力化が必要で早 く解決せ齐ばならないものに上槽の問題がある。これに ついてもいろいろな試みがなされているが未だ完全なる のは実施されていない。当所に括いても昨冬藪田式連続 㩁り機の試験をしたので，それを中心にして上槽につい て考察して見たい。

\section{（イ）清酒醮の滤過}

醪中に存在する粒子は A. 主にオリとなるもの，B. 醳 母, C. 米粒扔よびその崩壊物でこれが粕の大部分を占め ている。この部分を濾別するのに 4 14 メッシュの䇛を 用いて試験した結果 10 メッシュの穊が最も効果的であ るこことを知った ${ }^{12)}$ 。なピストン加圧（恒圧）による 濾過試験の結果, 濾液の $90 \%$ 排出点（醪ならば垂れ歩 合を $90 \%$ とすれば $81 \%$ 前後）までは濾過により分離 されそれ以後は圧密であろうと推察された ${ }^{10) 。}$

\section{（口）酒粕の蒸発残渣}

上槽直後の酒粕中には未だ揮発成分や清酒成分を含ん でいるが，その量は㩁り方によって異なりよく搾れ粕 は揮発分が少なく搾りが不充分のときは揮発分が多い。 通常の粕歩合は粕中に含まれている清酒量まで計算に入 れているので米粒の溶解歩合と上槽の巧拙とを加算した ものといえる。従って上槽の巧拙のみを知るためにはこ れを区別して考えねばならない。一般の酒粕について調

\begin{tabular}{|c|c|c|}
\hline$(\%)$ & $47.1 \sim 36.7$ & 平均 \\
\hline 蒸発残渣 $(\%)$ & 8. $26 \sim 4.49$ & 匀 \\
\hline 歩合 $(\%)$ & $31.4 \sim 15.6$ & 平均 \\
\hline
\end{tabular}
查した結果は次のようであった ${ }^{10)}$ 。

粕中の清酒の蒸発残渣を差引いた值即ち

$\begin{array}{lrrr}\text { 真の粕の 蒸 発 残 渣 (\%) } & 44.7 \sim 31.7 & \text { 平均 } 38.5 \\ \text { 白米に対する真の粕歩合 (\%) } & 13.57 \sim 5.59 & \text { 平均 } 8.26\end{array}$

当所に执いて普通の袋法とこの摍り機による粕を比較

\begin{tabular}{|c|c|}
\hline 粕の蒸発残渣 $(\%)$ & $\begin{array}{l}\text { 袋 法 } \\
53 \sim 42\end{array}$ \\
\hline 真の粕の蒸発残查 $(\%)$ & $51 \sim 38$ \\
\hline
\end{tabular}
した結果は次のようである。

㩁り機の粕の方が揮発分が多かった。また袋法は見掛 けの粕歩合 $22 \%$ 前後, 真の粕歩合 $9 \%$ 前後でその差は 14 13\% のものが多いのに，搾り機は前者が $32 \sim 36 \%$, 
(1034)

後者 9 11\%でその差 $20 \%$ 位のものが多数であった。 これらの数字から袋法の方がよく搾れていることがわか る。

\section{（ハ）濾過面皘について}

袋法の有効滤過面積は袋の口の折り曲げによって濾過 面として使用されない部分を除くと

$0.275 \mathrm{~m}^{2} /$ 枚 $(27 \mathrm{~cm} \times 50 \mathrm{~cm} \times 2)$ となり

㩁り機はゴム・パッキンの压縮で内面にのびて濾過面 をふさぐ面積を差引くと

$1,210 \mathrm{~m}^{2} /$ 枚 $(55 \mathrm{~cm} \times 110 \mathrm{~cm} \times 2)$ となる。

これをるとにして濾過面積と醪，粕，清酒の量比を調 査した結果は次のようになる。

$\begin{array}{lcc} & \text { 袋 法 } & \text { 㩁り機 } \\ \text { 酸量 } l / \text { 㥁過面 } \mathrm{m}^{2} & 27 \sim 32 & 19 \sim 30 \\ \text { 粕量 } \mathrm{kg} / \text { 滤過面 } \mathrm{m}^{2} & 2.2 \sim 3.9 & 2.2 \sim 3.2 \\ \text { 清酒量 } l / \text { 滤過面 } \mathrm{m}^{2} & 19 \sim 28 & 13 \sim 26\end{array}$

袋法は最初に入れる醪量が大略一定であるから大差な いが，控り機は機械の大小により初めから濾過面積が一 定しているのに予定量の醪が送入できなかったりするた めに差が大きくなる。したがってまず予定量の醪を送入 することが必要である。

\section{（二） 粕の厚さ}

袋法では 2.5 5.0 mm の厚さの粕が多い。㩁り機で は同じ濾過板の粕は平均した厚さの板粕となるが, ゴム パッキンがはずれた濾過板やその前後の板上では数倍の 厚さになるものがあり $3 \sim 17 \mathrm{~mm}$ の間で差が大きかっ た。そして厚い粕は軟かく（蒸発残渣が少なく）㩁り足 りないよらであった。それらを袋法と同程度まで㩁るた

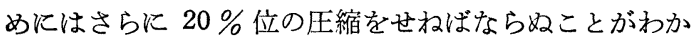
った。

\section{（木）滤過所要時間}

普通袋法のときは予定清酒量の $85 \%$ 附近までは非常
に早く濾過され全上槽時間の $1 / 3$ 位の時間しか要しない が，終りに近づくと時間がかかる。㩁り機は袋法よりも 幾らか短時間で清酒量 $50 \%$ までは明らかに早く全時間 の $15 \%$ 位であったがそれ以後は袋法と大差がない。し かし㩁り機は上槽の初めから早く清澄な清酒となりオリ 量が少なかった。また清酒醪の上槽はヶーキ濾過による ものであると想像されるので余り細かい濾布を使用する 必要はないように考学られた。

\section{（へ）今後の改良点}

薮田式連続㩁り機は醪の送り込みと压摧が自動的で且 つ粕離しが簡単であるから上槽の省力化には大いに役立 つものであるが，現在のままでは前述のように充分しぼ れ切れない欠点があり，また高田氏13)のいうように機械 の耐久力にも問題がありそうである。

この改良に対しては機械的な創意工夫と同時に清酒醪 の濾過理論の解明が必要だと思うので私達も大いに協力 して1日も早く完全な機械にしたいものだと考兄てい る。

以上酒造の省力化について最近の研究と感想を簡単に 述べたが少しでも御参考になれば誠に幸いである。

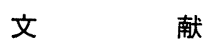

1) 金山尚明：醸造論文集 19 号, 49 (昭 39).

2) 山田正一・他：本誌，37. 765 (昭 17).

3) 山田正一・他: 酸報, 128. 256 (环 14).

4) 山田正一・他：本誌, 51. 107 (昭 31).

5) 外池良三・他：本誌, 51. 555 (昭 31).

6) 石川正人：農化昭 39 年大会, 講演

7) 河村稳・他: 愛食試験, 3. 5 (昭 37).

8) 河村稳・他：本誌, 54, 602 (昭 34).

9）河村稳・他：愛食試報, 4. 15 (昭 38).

10）愛食試・昭和 38 年度 - 清榊武駼製造報告書

11) 酸造論文集, 19.29 (昭 39).

12）愛食試: 昭和 37 年度・清酒試験製造報告書

13）高田小三郎：本誌，59. 663 (昭 39).

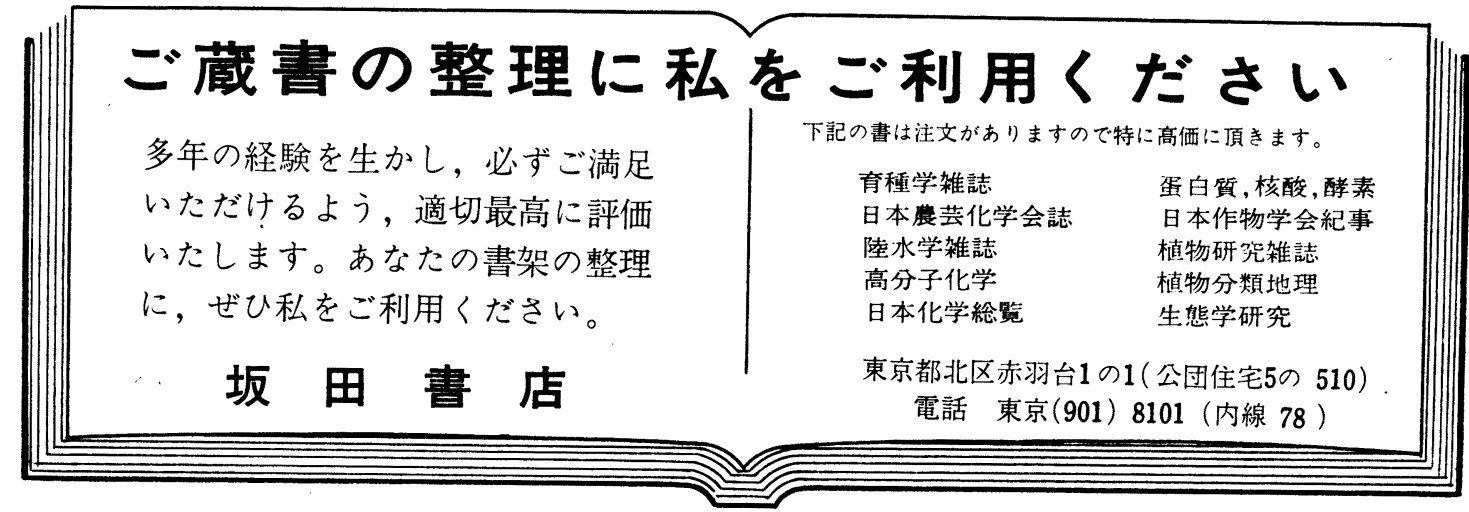

